\title{
UPAYA MENINGKATKAN KOMPETENSI GURU DALAM MENYUSUN RENCANA PROGRAM PEMBELAJARAN HARIAN MELALUI BIMBINGAN BERKELANJUTAN DI TK PGRI PRAYA
}

\author{
SITI SA'ADAH \\ Kepala TK PGRI Praya, fitriauliapertiwi@gmail.com
}

\begin{tabular}{l} 
INFO ARTIKEL \\
\hline Riwayat Artikel: \\
Diterima: 01-03-2018 \\
Disetujui: 12-04-2018 \\
\hline
\end{tabular}

Kata Kunci:

Bimbingan

Berkelanjutan,

Komptensi Guru

\begin{abstract}
ABSTRAK
Abstrak: Penelitian Tindakan Sekolah 2 siklus yang terdiri dari 4 tahapan yaitu tahap perencanaan, tahap observasi, tahap evaluasi, dan tahap refleksi dengan tujuan untuk mengetahui apakah Bimbingan berkelanjutan dapat meningkatkan kompetensi guru dalam menyusun Rencana Pembelajaran Harian. Metode yang digunakan adalah observasi, interview, dokumentasi. Diperoleh hasil terdapat peningkatan $25 \%$ dari $75 \%$ pada siklus I menjadi $100 \%$ pada siklus II. Disimpulkan bahwa penerapan Bimbingan berkelanjutan dapat meningkatkan kompetensi Guru TK PGRI Praya Tahun 2017/2018 dalam menyusun Rencana Pembelajaran Harian.
\end{abstract}

\begin{abstract}
School Action Research 2 cycles consisting of 4 stages: planning stage, observation stage, evaluation stage, and reflection phase with the aim to find out whether continuous Guidance can improve teacher competence in preparing Daily Learning Plan. The method used is observation, interview, documentation. The results obtained are $25 \%$ increase from $75 \%$ in cycle I to $100 \%$ in cycle II. It is concluded that the application of continuous Guidance can improve the competence of PGRI Praya Teacher of Year 2017/2018 in preparing Daily Learning Plan.
\end{abstract}

\section{A. LATAR BELAKANG}

Pendidikan merupakan modal dasar dalam pengembangan sumber daya manusia dan merupakan kebutuhan masyarakat yang ingin maju. Komponenkomponen sistem pendidikan yang mencakup sumber daya manusia dapat digolongkan menjadi dua yaitu: tenaga kependidikan guru dan nonguru . Menurut Undang-Undang Nomor 20 tahun 2003 tentang Sistem Pendidikan Nasional menyatakan, "komponenkomponen sistem pendidikan yang bersifat sumber daya manusia dapat digolongkan menjadi tenaga pendidik dan pengelola satuan pendidikan ( penilik, pengawas, peneliti dan pengembang pendidikan).” Tenaga gurulah yang mendapatkan perhatian lebih banyak di antara komponen-komponen sistem pendidikan. Tingginya perhatian Pemerintah terhadap guru antara lain dapat dilihat dengan adanya kebijakan khusus terhadap kenaikan tunjangan fungsional guru dan sertifikasi guru.

Upaya - upaya untuk mempersiapkan guru menjadi profesional telah banyak dilakukan. Namun Kenyataan menunjukkan bahwa tidak semua guru memiliki kinerja yang baik dalam melaksanakan tugasnya. Hal itu ditunjukkan dengan kenyataan (1) guru sering mengeluh kurikulum yang berubah-ubah, (2) guru sering mengeluhkan kurikulum yang syarat dengan beban, (3) Adanya siswa yang tidak mau mengikuti kegiatan yang di sebabkan cara mengajar guru yang tidak menarik, (4) masih belum dapat dijaminnya kualitas pendidikan sebagai mana mestinya.

Berdasarkan kenyataan betapa berat dan kompleksnya tugas serta peran guru tersebut, oleh karena itu perlu diadakan supervisi atau pembinaan terhadap guru secara terus menerus dan berkelanjutan sebagai upaya untuk meningkatkan kinerjanya. Kinerja guru perlu ditingkatkan agar usaha membimbing siswa untuk belajar dapat berkembang dengan baik.

Proses pengembangan kinerja guru terjadi terbentuk dalam kegiatan belajar mengajar di tempat mereka bekerja. Pembinaan dan supervisi kepala sekolah sangat mempengaruhi kinerja seorang Guru. pembinaan dan supervisi kepala sekolah. Dalam pelaksanaan KTSP dan Kurikulum 2013 Guru di tuntut untuk selalu meningkatkan kemampuannya dalam mengelola proses pembelajaran secara efektif dan efisien. Tingkat produktivitas sekolah dalam memberikan pelayanan secara efisien kepada pengguna ( peserta didik, masyarakat ) akan sangat tergantung pada kualitas gurunya yang terlibat langsung dalam proses pembelajaran dan keefektifan mereka dalam melaksanakan tanggung jawab individual dan kelompok.

Menurut pendapat peneliti kualitas pendidikan sangat ditentukan oleh kemampuan sekolah dalam mengelola proses pembelajaran, dan lebih khusus lagi adalah proses pembelajaran yang terjadi di kelas, mempunyai andil dalam menentukan kualitas pendidikan konsekuensinya, adalah guru harus mempersiapkan (merencanakan ) segala sesuatu agar proses pembelajaran di kelas berjalan dengan efektif". Itu berarti bahwa guru sebagai fasilitator yang mengelola proses pembelajaran di kelas mempunyai andil dalam menentukan kualitas pendidikan. Konsekuensinya adalah guru harus mempersiapkan (merencanakan) segala sesuatu agar proses pembelajaran di kelas berjalan dengan efektif.

Perencanaan pembelajaran merupakan langkah yang sangat penting sebelum pelaksanaan pembelajaran. Perencanaan yang matang diperlukan supaya 
pelaksanaan pembelajaran berjalan secara efektif. Perencanaan pembelajaran dituangkan ke dalam Rencana Pelaksanaan Pembelajaran menggunakan (RPPM) dan Rencana Pelaksanaan Pembelajaran Harian (RPPH) atau beberapa istilah lain seperti desain pembelajaran, skenario pembelajaran dan lain sebagainya. RPPM dan RPPH memuat tingkat pencapaian perkembangan, indikator yang akan dicapai, materi yang akan dipelajari, metode pembelajaran, langkah pembelajaran, media pembelajaran, dan sumber belajar serta penilaian.

Guru harus dapat berperan sebagai desainer (perencana), implementator (pelaksana), dan evaluator (penilai) kegiatan pembelajaran. Guru merupakan faktor yang paling dominan karena di tangan gurulah keberhasilan pembelajaran dapat dicapai. Kualitas mengajar guru secara langsung maupun tidak langsung dapat mempengaruhi kualitas pembelajaran pada umumnya. Seorang guru dapat dikatakan profesional apabila (1)benar - benar serius melaksanakan tugas profesinya dengan baik, (2) bangga dengan tugas profesinya, ( 3) selalu menjaga dan berupaya meningkatkan kompetensinya, (4) bekerja dengan sadar dan sungguh - sungguh tanpa harus diawasi, (5) menjaga dan memelihara nama baik profesinya, (6) mensyukuri atas imbalan yang diperoleh dari profesinya.

Peraturan Pemerintah Nomor 19 Tahun 2005 tentang 8 Standar Nasional Pendidikan menyatakan standar proses merupakan salah satu SNP untuk satuan pendidikan dasar dan menengah yang mencakup: 1) Perencanaan proses pembelajaran, 2) Pelaksanaan proses pembelajaran, 3) Penilaian hasil pembelajaran, 4) dan pengawasan proses pembelajaran.

Silabus dan RPPH dikembangkan oleh guru pada satuan pendidikan. Guru pada satuan pendidikan berkewajiban menyusun silabus, RPPM dan RPPH secara lengkap dan sistematis agar pembelajaran dapat berlangsung secara aktif, kreatif, menyenangkan, menantang, memotivasi peserta didik untuk berpartisipasi aktif, serta memberikan ruang yang cukup bagi prakarsa, kreativitas, dan kemandirian sesuai dengan bakat, minat dan perkembangan fisik serta psikologis peserta didik.

Masalah yang terjadi di lapangan masih ditemukan adanya guru (baik di sekolah negeri maupun swasta) yang tidak bisa memperlihatkan RPPM dan RPPH yang dibuat dengan alasan ketinggalan di rumah dan bagi guru yang sudah membuat RPPM dan RPPH masih ditemukan adanya guru yang belum melengkapi komponen tujuan pembelajaran dan penilaian, serta langkah-langkah kegiatan pembelajarannya masih dangkal. Pada komponen penilaian ( penskoran) sebagian besar guru tidak lengkap membuatnya dengan alasan sudah tahu dan ada di kepala. Sedangkan pada komponen tujuan pembelajaran, materi ajar, metode pembelajaran, dan sumber belajar sebagian besar guru sudah membuatnya. Masalah yang lain yaitu sebagian besar guru khususnya di sekolah swasta belum mendapatkan pelatihan pengembangan RPPH. Selama ini guru-guru yang mengajar di sekolah swasta sedikit/jarang mendapatkan kesempatan untuk mengikuti berbagai Diklat Peningkatan Profesionalisme Guru dibandingkan sekolah negeri. Hal ini menyebabkan banyak guru yang belum tahu dan memahami penyusunan/pembuatan RPPH secara baik/lengkap. Beberapa guru mengadopsi RPPH orang lain. Hal ini peneliti ketahui pada saat mengadakan supervisi akademik (supervisi kunjungan kelas) sekolah binaan. Permasalahan tersebut berpengaruh besar terhadap pelaksanaan proses pembelajaran.

Dengan keadaan yang demikian, peneliti sebagai kepala sekolah berusaha untuk memberi bimbingan berkelanjutan pada guru di sekolah kami dalam menyusun RPPM dan RKH secara lengkap sesuai dengan tuntutan pada standar proses dan standar penilaian yang merupakan bagian dari standar nasional pendidikan.

Rencana Pelaksanaan Pembelajaran harus dibuat agar kegiatan pembelajaran berjalan sistematis dan mencapai tujuan pembelajaran. Tanpa Rencana Program Pembelajaran, biasanya pembelajaran menjadi tidak terarah. Oleh karena itu, guru harus mampu menyusun RPPM dan RKH dengan lengkap berdasarkan silabus yang disusunnya. Rencana Program Pembelajaran sangat penting bagi seorang guru karena merupakan acuan dalam melaksanakan proses pembelajaran.

\section{B. METODE PENELITIAN}

Penelitian Tindakan Sekolah dilaksanakan melalui dua siklus untuk melihat peningkatan kompetensi guru dalam menyusun Rencana Pelaksanaan Pembelajaran (RPPH\&RPPM). Sebelum PTS dilaksanakan, dibuat berbagai input instrument yang digunakan untuk mendapatkan data dan informasi. Yang menjadi subyek dalam PTS ini adalah guru TK PGRI Praya Jalan Jempiring No.19 Mispalah Prapen Kec.Praya Kab. Loteng

\section{Pengumpulan Data}

a. Wawancara dipergunakan untuk mendapatkan data atau informasi tentang sejauh pemahaman guru tentang RPPH.

b. Observasi dipergunakan untuk mengumpulkan data dan mengetahui kompetensi guru dalam menyusun Rencana Pelaksanaan Pembelajaran dengan lengkap.

c. Diskusi dilakukan antara peneliti dengan guru.

\section{Prosedur Penelitian}

Penelitian ini berbentuk Penelitian Tindakan Sekolah (School Action Research), yaitu sebuah penelitian yang merupakan kerjasama antara peneliti dan guru, dalam meningkatkan kemampuan guru agar menjadi lebih baik dalam menyusun rencana pelaksanaan pembelajaran.

Metode yang digunakan dalam penelitian ini adalah metode deskriptif, dengan menggunakan teknik persentase untuk melihat peningkatan yang terjadi dari siklus I ke siklus II. "Metode deskriptif dapat diartikan sebagai prosedur pemecahan masalah yang diselidiki dengan menggambarkan/melukiskan keadaan subjek/objek penelitian (seseorang, lembaga, masyarakat, dan lain-lain) pada saat sekarang berdasarkan fakta-fakta yang tampak atau sebagaimana adanya (Nawawi, 1985:63). Dengan metode ini peneliti berupaya menjelaskan data yang peneliti kumpulkan melalui komunikasi langsung atau wawancara, observasi/pengamatan, dan diskusi yang berupa persentase atau angka-angka.

Penelitian ini bertujuan untuk mendeskripsikan kesulitan-kesulitan yang dialami oleh guru dalam menyusun RPPH. Selanjutnya peneliti memberikan alternatif atau usaha guna meningkatkan kemampuan 
guru dalam membuat rencana pelaksanaan pembelajaran. Hal-hal penting yang harus diperhatikan dalam Penelitian Tindakan Sekolah, menurut Sudarsono, F.X, (1999:2) yakni:

a. Rencana: Tindakan apa yang akan dilakukan untuk meningkatkan kompetensi guru dalam menyusun RKH secara lengkap. Solusinya yaitu dengan melakukan : a) wawancara dengan guru dengan menyiapkan lembar Angket wawancara, b) Diskusi dalam suasana yang menyenangkan dan c) memberikan bimbingan dalam menyusun $\mathrm{RKH}$ secara lengkap.

b. Pelaksanaan: Apa yang dilakukan oleh peneliti sebagai upaya meningkatkan kompetensi guru dalam menyusun RPPH yang lengkap yaitu dengan memberikan bimbingan berkelanjutan pada guru TK PGRI Praya .

c. Observasi: Peneliti melakukan pengamatan terhadap RPPH yang telah dibuat untuk mengetahui seberapa jauh kemampuan guru dalam menyusun RPPH dengan lengkap, hasil atau dampak dari tindakan yang telah dilaksanakan oleh guru dalam mencapai sasaran. Selain itu juga peneliti mencatat halhal yang terjadi dalam pertemuan dan wawancara. Rekaman dari pertemuan dan wawancara akan digunakan untuk analisis dan komentar kemudian.

d. Refleksi: Peneliti mengkaji, melihat, dan mempertimbangkan hasil atau dampak dari tindakan yang telah dilakukan. Berdasarkan hasil dari refleksi ini, peneliti bersama guru melaksanakan revisi atau perbaikan terhadap RPPH yang telah disusun agar sesuai dengan rencana awal yang mungkin saja masih bisa sesuai dengan yang peneliti inginkan.

Prosedur penelitian adalah suatu rangkaian tahaptahap penelitian dari awal sampai akhir. Penelitian ini merupakan proses pengkajian sistem berdaur sebagaimana kerangka berpikir yang dikembangkan oleh Suharsimi Arikunto dkk. Prosedur ini mencakup tahaptahap: (1) perencanaan, (2) pelaksanaan, (3) pengamatan, dan (4) refleksi. Keempat kegiatan tersebut saling terkait dan secara urut membentuk sebuah siklus. Penelitian Tindakan Sekolah merupakan penelitian yang bersiklus, artinya penelitian dilakukan secara berulang dan berkelanjutan sampai tujuan penelitian dapat tercapai."

\section{Rencana Pelaksanaan}

a. Siklus Pertama (Siklus I)

1) Peneliti merencanakan tindakan pada siklus I (membuat format/instrumen wawancara, penilaian RPPH, rekapitulasi hasil penyusunan RPPH).

2) Peneliti memberi kesempatan kepada guru untuk mengemukakan kesulitan atau hambatan dalam menyusun Rencana Pelaksanaan Pembelajaran.

3) Peneliti menjelaskan kepada guru tentang pentingnya RPPH dibuat secara lengkap.

4) Peneliti memberikan bimbingan dalam pengembangan RPPH.

5) Peneliti melakukan observasi/pengamatan terhadap RPPH yang telah dibuat guru.
6) Peneliti melakukan revisi atau perbaikan penyusunan rencana pelaksanaan pembelajaran yang lengkap.

7) Peneliti dan guru melakukan refleksi.

b. Siklus Kedua (Siklus II)

1) Peneliti merencanakan tindakan pada siklus II yang mendasarkan pada revisi/perbaikan pada siklus I, seperti menugasi guru menyusun RPPH yang kedua, mengumpulkan, dan melakukan pembimbingan penyusunan RPPH.

2) Peneliti melaksanakan tindakan sesuai dengan rencana pada siklus II.

3) Peneliti melakukan observasi/pengamatan terhadap RPPH yang telah dibuat guru.

4) Peneliti melakukan perbaikan atau revisi penyusunan RPPH.

5) Peneliti dan guru melakukan refleksi.

\section{Indikator Pencapaian Hasil}

Peneliti mengharapkan secara rinci indikator pencapaian hasil paling rendah $78 \%$ guru membuat kesebelas komponen Rencana Pelaksanaan Pembelajaran sebagai berikut.

a. Komponen identitas mata pelajaran diharapkan ketercapaiannya $100 \%$.

b. Komponen standar kompetensi diharapkan ketercapaiannya $85 \%$.

c. Komponen kompetensi dasar diharapkan ketercapaiannya $85 \%$.

d. Komponen indikator pencapaian kompetensi diharapkan ketercapaiannya $75 \%$.

e. Komponen tujuan pembelajaran diharapkan ketercapaiannya $75 \%$.

f. Komponen materi pembelajaran diharapkan kecercapaian $75 \%$.

g. Komponen alokasi waktu diharapkan ketercapaiannya $75 \%$.

h. Komponen metode pembelajaran diharapkan kecercapaiannya $75 \%$.

i. Komponen langkah-langkah kegiatan pembelajaran diharapkan ketercapaiannya $70 \%$.

j. Komponen sumber belajar diharapkan ketercapaiannya $70 \%$.

k. 11. Komponen penilaian diharapkan ketercapaiannya $75 \%$.

\section{HASIL DAN PEMBAHASAN}

Dari hasil wawancara peneliti memperoleh informasi bahwa semua guru belum tahu kerangka penyusunan RPPH, hanya sekolah yang memiliki dokumen standar proses (satu buah), dua orang guru yang pernah mengikuti pelatihan pengembangan RPPH tetap belum bisa maksimal, umumnya guru mengadopsi dan mengadaptasi RPPH, kebanyakan guru tidak tahu dan tidak paham menyusun RPPH secara lengkap, mereka setuju bahwa guru harus menggunakan RPPH dalam melaksanakan proses pembelajaran yang dapat dijadikan acuan/pedoman dalam proses pembelajaran. Selain itu, kebanyakan guru belum tahu dengan komponen-komponen RPPH secara lengkap.

Berdasarkan hasil observasi peneliti terhadap RPPH yang dibuat guru (khusus pada siklus I), diperoleh informasi/data bahwa masih ada guru yang tidak melengkapi RPPH-nya dengan komponen dan sub- 
subkomponen RPPH tertentu, misalnya komponen indikator dan penilaian hasil belajar (pedoman penskoran). Rumusan kegiatan siswa pada komponen langkah-langkah kegiatan pembelajaran masih kurang tajam, interaktif, inspiratif, menantang, dan sistematis.

Dilihat dari segi kompetensi guru, terjadi peningkatan dalam menyusun Rencana Pelaksanaan Pembelajaran dari siklus ke siklus . Hal itu dapat dilihat pada lampiran Rekapitulasi Hasil Penyusunan RPPH dari Siklus ke Siklus.

\section{Siklus I (Pertama)}

Siklus pertama terdiri dari empat tahap yakni: (1) perencanaan, (2) pelaksanaan, (3) observasi, dan (4) refleksi seperti berikut ini.

1. Perencanaan ( Planning )

a. Membuat lembar wawancara

b. Membuat format/instrumen penilaian RPPH

c. Membuat format rekapitulasi hasil penyusunan RPPH siklus I dan II

d. Membuat format rekapitulasi hasil penyusunan RPPH dari siklus ke siklus

2. Pelaksanaan (Acting)

Pada saat awal siklus pertama indikator pencapaian hasil dari setiap komponen RPPH belum sesuai/tercapai seperti rencana/keinginan peneliti. Hal itu dibuktikan dengan masih adanya komponen RPPH yang belum dibuat oleh guru. Sebelas komponen RPPH yakni: 1) identitas mata pelajaran, 2) standar kompetensi, 3) kompetensi dasar, 4) indikator pencapaian kompetensi, 5) tujuan pembelajaran, 6) materi ajar, 7) alokasi waktu, 8) metode pembelajaran, 9) langkah-langkah kegiatan pembelajaran, 10) sumber belajar, 11) penilaiaan hasil belajar ( soal, pedoman penskoran, dan kunci jawaban). Hasil observasi pada siklus kesatu dapat dideskripsikan bahwa : Satu orang tidak melengkapinya dengan teknik dan bentuk instrumen.

a. Satu orang tidak melengkapinya dengan teknik, bentuk instumen, soal, pedoman penskoran, dan kunci jawaban.

b. Dua orang tidak melengkapinya dengan teknik, pedoman penskoran, dan kunci jawaban.

c. Satu orang tidak melengkapinya dengan soal, pedoman penskoran, dan kunci jawaban.

d. Satu orang tidak melengkapinya dengan pedoman penskoran dan kunci jawaban. Selanjutnya mereka dibimbing dan disarankan untuk melengkapinya.

\section{Siklus II (Kedua)}

Siklus kedua juga terdiri dari empat tahap yakni: (1) perencanaan, (2) pelaksanaan, (3) observasi, dan (4) refleksi. Hasil observasi pada siklus kedua dapat dideskripsikan berikut ini:

Observasi dilaksanakan Selasa, 23 September 2014, terhadap semua guru. Semuanya menyusun RPPH, tapi masih ada guru yang keliru dalam menentukan kegiatan siswa dalam langkah-langkah kegiatan pembelajaran dan metode pembelajaran, serta tidak memilah/ menguraikan materi pembelajaran dalam subsub materi. Untuk komponen penilaian hasil belajar, dapat dikemukakan sebagai berikut.

Satu orang keliru dalam menentukan teknik dan bentuk instrumennya.
Satu orang keliru dalam menentukan bentuk instrumen berdasarkan teknik penilaian yang dipilih.

Dua orang kurang jelas dalam menentukan pedoman penskoran.Satu orang tidak menuliskan rumus perolehan nilai siswa.

Selanjutnya mereka dibimbing dan disarankan untuk melengkapinya.

Penelitian Tindakan Sekolah dilaksanakan di TK PGRI Praya yang merupakan sekolah tempat peneliti bertugas sebagai kepala sekolah berstatus swasta, terdiri atas enam orang guru, dan dilaksanakan dalam dua siklus. keenam guru tersebut menunjukkan sikap yang baik dan termotivasi dalam menyusun RPPH dengan lengkap. Hal ini peneliti ketahui dari hasil pengamatan pada saat melakukan wawancara dan bimbingan penyusunan RPPH.

Selanjutnya dilihat dari kompetensi guru dalam menyusun RPPH, terjadi peningkatan dari siklus ke siklus.

\section{Komponen Identitas Mata Pelajaran}

Pada siklus pertama semua guru (dua orang) mencantumkan identitas mata pelajaran dalam RPPH-nya (melengkapi RPPH-nya dengan identitas mata pelajaran). Jika dipersentasekan, $100 \%$ (sangat baik). Pada siklus kedua kedua guru tersebut mencantumkan identitas mata pelajaran dalam RPPH-nya. Semuanya mendapat skor 4 (sangat baik). Jika dipersentasekan, 100\%.

\section{Komponen Standar Kompetensi}

Pada siklus pertama semua guru mencantumkan standar kompetensi dalam RPPH-nya (melengkapi RPPH-nya dengan standar kompetensi). Jika dipersentasekan, 100\%. Masing-masing guru mendapat skor yang baik..

\section{Komponen Kompetensi Dasar}

Pada siklus pertama semua guru (dua orang) mencantumkan kompetensi dasar dalam RPPHnya (melengkapi RPPH-nya dengan kompetensi dasar). Jika dipersentasekan, $75 \%$. Satu orang guru masing-masing mendapat skor 1, 2, dan 3 (kurang baik, cukup baik, dan baik). Satu orang guru yang lain mendapat skor 4 (sangat baik). Pada siklus kedua keenam guru tersebut mencantumkan kompetensi dasar dalam RPPHnya. dua orang mendapat skor 4 (sangat baik). Jika dipersentasekan, $100 \%$, terjadi peningkatan $25 \%$ dari siklus I.

\section{Komponen Indikator Pencapaian}

\section{Kompetensi}

Pada siklus pertama saru orang guru mencantumkan indikator pencapaian kompetensi dalam RPPH-nya (melengkapi RPPH-nya dengan indikator pencapaian kompetensi). Sedangkan satu orang tidak mencantumkan/melengkapinya dari siklus I.

\section{Komponen Tujuan Pembelajaran}

Pada siklus pertama semua guru (Empat orang) mencantumkan tujuan pembelajaran dalam RPPH-nya (melengkapi RPPH-nya dengan tujuan pembelajaran). Jika dipersentasekan, $75 \%$. dua orang guru mendapat skor 3 (baik. Pada siklus kedua semua guru tersebut mencantumkan tujuan pembelajaran dalam RPPH-nya. Jika 
dipersentasekan, $100 \%$, terjadi peningkatan $25 \%$ dari siklus I.

6. Komponen Materi Ajar

Pada siklus pertama semua guru (dua orang) mencantumkan materi ajar dalam RPPH-nya (melengkapi RPPH-nya dengan materi ajar). Jika dipersentasekan, 75\%. dua orang mendapat skor 3 (baik). Pada siklus kedua semua guru tersebut mencantumkan materi ajar dalam RPPH-nya. Keduanya orang mendapat skor 4 (sangat baik). Jika dipersentasekan, 100\%, terjadi peningkatan $25 \%$ dari siklus I.

\section{Komponen Alokasi Waktu}

ada siklus pertama semua guru (dua orang) mencantumkan alokasi waktu dalam RPPH-nya (melengkapi RPPH-nya dengan alokasi waktu). Semuanya mendapat skor 3 (baik). Jika dipersentasekan, $75 \%$. Pada siklus kedua semua guru tersebut mencantumkan alokasi waktu dalam RPPH-nya. Dua orang mendapat skor 4 (sangat baik). Jika dipersentasekan, 100\%, terjadi peningkatan $25 \%$ dari siklus I.

8. Komponen Metode Pembelajaran

Pada siklus pertama semua guru (dua orang) mencantumkan metode pembelajaran dalam RPPH-nya (melengkapi RPPH-nya dengan metode pembelajaran). Jika dipersentasekan, 75\%. dua orang mendapat skor 3 (baik). Pada siklus kedua guru tersebut mencantumkan metode pembelajaran dalam RPPH-nya. Semua orang mendapat skor 4 (sangat baik). Jika dipersentasekan, $100 \%$, terjadi peningkatan $25 \%$ dari siklus I.

9. Komponen Langkah-Langkah Kegiatan Pembelajaran

Pada siklus pertama semua guru (dua orang) mencantumkan langkah-langkah kegiatan pembelajaran dalam RPPH-nya (melengkapi RPPH-nya dengan langkah-langkah kegiatan pembelajaran). Jika dipersentasekan, $75 \%$. Kedua guru tersebut orang mendapat skor 3 (baik). Pada siklus kedua, semua guru tersebut mencantumkan langkah-langkah kegiatan pembelajaran dalam RPPH-nya. Sehingga kedua guru tersebut mendapat skor 3 (baik). Jika dipersentasekan, $100 \%$, terjadi peningkatan $25 \%$ dari siklus I.

10. Komponen Sumber Belajar

Pada siklus pertama semua guru mencantumkan sumber belajar dalam RPPH-nya (melengkapi RPPH-nya dengan sumber belajar). Jika dipersentasekan, $100 \%$. Baik pada siklus I maupun siklus II

11. Komponen Penilaian Hasil Belajar

Pada siklus pertama semua guru mencantumkan penilaian hasil belajar dalam RPPH-nya meskipun sub-sub komponennya (teknik, bentuk instrumen), dan pedoman penskoran. Jika dipersentasekan, 62,50\%. satu orang mendapat skor 2 (cukup baik), dan satu orang mendapat skor 3 (baik). Pada siklus kedua semua guru tersebut mencantumkan penilaian hasil belajar dalam RPPH-nya meskipun ada guru yang masih keliru dalam menentukan teknik dan bentuk penilaiannya. Satu orang mendapat skor 3 (baik) dan satu orang mendapat skor 4 (sangat baik).
Jika dipersentasekan, $87,50 \%$, terjadi peningkatan $12,50 \%$ dari siklus I.

Berdasarkan pembahasan di atas terjadi peningkatan yang signifigan pada kompetensi guru dalam menyusun RPPH. Oleh karen itu dari penelitian diatas dapat disimpulkan perlunya adanya pembinaan kepada guru dalam penyusunan RPPH, RPPM dan perangkat administrasi pembelajaran lainnya. Sehingga dengan adanya pembinaan tersebut guru-guru semakin lebih kompeten dalam menyusun administrasi pembelajarannya.

\section{SIMPULAN DAN SARAN}

\section{Simpulan:}

a. Bimbingan berkelanjutan dapat meningkatkan motivasi guru dalam menyusun RPPH dengan lengkap. Guru menunjukkan keseriusan dalam memahami dan menyusun RPPH apalagi setelah mendapatkan bimbingan pengembangan/penyusunan RPPH dari peneliti. Informasi ini peneliti peroleh dari hasil pengamatan pada saat mengadakan wawancara dan bimbingan pengembangan/penyusunan RPPH kepada para guru.

b. Bimbingan berkelanjutan dapat meningkatkan kompetensi guru dalam menyusun RPPH. Hal itu dapat dibuktikan dari hasil observasi /pengamatan yang memperlihatkan bahwa terjadi peningkatan kompetensi guru dalam menyusun RPPH dari siklus ke siklus .

\section{Saran:}

a. Motivasi yang sudah tertanam khususnya dalam penyusunan RPPH hendaknya terus dipertahankan dan ditingkatkan/ dikembangkan .

b. RPPH yang disusun/dibuat hendaknya mengandung komponen-komponen RPPH secara lengkap dan baik karena RPPH merupakan acuan/pedoman dalam melaksanakan pembelajaran.

c. Dokumen RPPH hendaknya dibuat minimal dua rangkap, satu untuk arsip sekolah dan satunya lagi untuk pegangan guru dalam melaksanakan proses pembelajaran.

\section{UCAPAN TERIMA KASIH}

Dengan penuh rasa hormat, saya ucapkan teimakasih kepada:

Kepala Dinas Pendidikan yang telah memfasilitasi, mengizinkan penulis untk mengadakan penelitian hingga dapat terlaksana dengan baik.

Ketua PGRI Kabupaten Lombok Tengah dan Kepala UPT Pelayanan PAUD dan Pendidikan Dasar Kecamatan Praya yang turut memotivasi untuk terlaksananya penelitian di sekolah secara reguler.

Guru-guru yang telah memberi dukungan baik secara moral maupun tindakan langsung dalam pelaksanaan penelitian ini. 


\section{DAFTAR RUJUKAN}

[1] Daradjat, Zakiyah. 1980. Kepribadian Guru. Jakarta: Bulan Bintang.

[2] Dewi, Kurniawati Eni . 2009. Pengembangan Bahan Ajar Bahasa Dan Sastra Indonesia Dengan Pendekatan Tematis. Tesis. Surakarta: Program Pascasarjana Universitas Sebelas Maret.

[3] Depdiknas. 2003. UU RI No. 2O Tahun 2003 tentang Sistem Pendidikan Nasional. Jakarta: Depdiknas.

[4] 2004. Standar Kompetensi Guru Sekolah Dasar. Jakarta: Depdiknas.

[5] 2005. UU RI No. 14 Tahun 2005 tentang Guru dan Dosen. Jakarta: Depdiknas.

[6] 2005. Standar Nasional Pendidikan. Jakarta: Depdiknas.

[7] 2007. Permendiknas RI No. 41 Tahun 2007a tentang Standar Proses. Jakarta: Depdiknas.

[8] 2008. Alat Penilaian Kemampuan Guru. Jakarta: Depdiknas.

[9] 2009. Petunjuk Teknis Pembuatan Laporan Penelitian Tindakan Sekolah Sebagai Karya Tulis Ilmiah Dalam Kegiatan Pengembangan Profesi Guru. Jakarta

[10] Fatihah, RM . 2008. Pengertian konseling (Http://eko13.wordpress.com, diakses 19 Maret 2009).

[11] Imron, Ali. 2000. Pembinaan Guru Di Indonesia. Malang: Pustaka Jaya.

[12] Kemendiknas. 2010. Penelitian Tindakan Sekolah. Jakarta.

[13]_ 2010. Supervisi Akademik. Jakarta.

[14] Kumaidi. 2008. Sistem Sertifikasi (http://massofa.wordpress.com diakses 10 Agustus 2009).

[15] Nawawi, Hadari. 1985. Metode Penelitian Bidang Sosial. Yogyakarta: Gadjah Mada University Press.

[16] Nurhadi. 2004. Kurikulum 2004. Jakarta: PT Gramedia Widiasarana Indonesia.

[17] Pidarta, Made . 1992. Pemikiran Tentang Supervisi Pendidikan. Jakarta: Bumi Aksara.

[18] Sudjana, Nana. 2009. Standar Kompetensi Pengawas Dimensi dan Indikator. Jakarta : Binamitra Publishing.

[19] Suharjono. 2003. Menyusun Usulan Penelitian. Jakarta: Makalah Disajikan Pada Kegiatan Pelatihan Tehnis Tenaga Fungsional Pengawas.

[20]Suparlan. 2005. Menjadi Guru Efektif. Yogyakarta: Hikayat Publishing.

[21] 2006. Guru Sebagai Profesi. Yogyakarta: Hikayat Publishing.

[22]_ 2014 Enslikopedia Pendidikan Anak Usia Dini

[23] Tim Redaksi Kamus Besar Bahasa Indonesia. Edisi kedua 